\title{
- \\ Article type : Original Article - Clinical Endocrinology \\ Lower muscle tissue is associated with higher pulse wave velocity: a systematic review and meta-analysis of observational study data
}

Alexander J. Rodríguez ${ }^{1}$, Md Nazmul Karim² ${ }^{2}$, Velandai Srikanth ${ }^{3}$, Peter Ebeling ${ }^{1,4}$ and David Scott ${ }^{1,4}$

${ }^{1}$ Bone and Muscle Health Research Group, Department of Medicine, School of Clinical Sciences at Monash Health, Faculty of Medicine, Nursing and Health Sciences, Monash University, Clayton, Australia ${ }^{2}$ Department of Epidemiology and Preventive Medicine, School of Public Health and Preventive Medicine, Faculty of Medicine, Nursing and Health Sciences, Monash University, Prahan, Australia

${ }^{3}$ Stroke and Ageing Research Group, Department of Medicine, School of Clinical Sciences, Faculty of Medicine, Nursing and Health Sciences, Monash University, Clayton, Australia

${ }^{4}$ Melbourne Medical School (Western Campus), Department of Medicine, The University of Melbourne, St Albans, Australia

\section{*Corresponding Author:}

Alexander J. Rodríguez

Bone and Muscle Health Research Group, Department of Medicine, School of Clinical Sciences at Monash Health, Faculty of Medicine, Nursing and Health Sciences, Monash University

Level 5, Block E, Monash Medical Centre, 246 Clayton Road, Clayton, Victoria, Australia 3168.

Phone: +6138572 2919 Fax: +61395946495 Email: alexander.rodriguez@monash.edu

Manuscript type: Systematic Review and Meta-analysis

Words: 4,314 (5,870 with references)

Declaration: The authors declare no competing interests

This is the author manuscript accepted for publication and has undergone full peer review but has not been through the copyediting, typesetting, pagination and proofreading process, which may lead to differences between this version and the Version of Record. Please cite this article as doi: $10.1111 / 1440-1681.12805$

This article is protected by copyright. All rights reserved 
Funding: This work was supported by Monash University

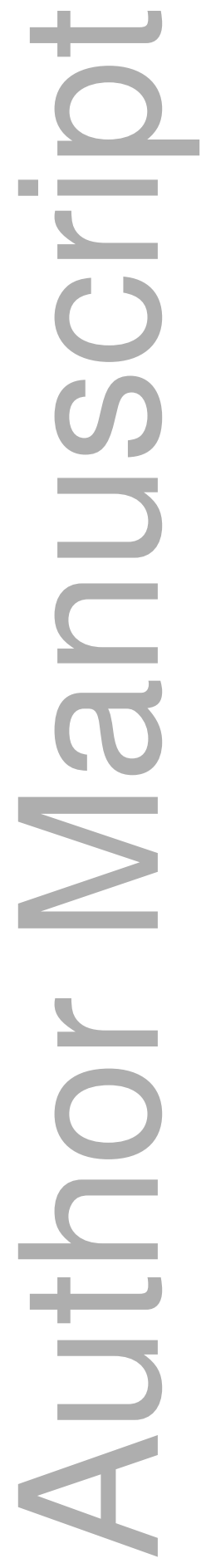

This article is protected by copyright. All rights reserved 


\section{Abstract}

Muscle loss and arterial stiffness share common risk factors and are commonly seen in the elderly. We aimed to synthesise the existing literature on studies that have examined this association. We searched electronic databases for studies reporting correlations or associations between a measure of muscle tissue and a measure of arterial stiffness. Meta-analysis was conducted using Fisher's Ztransformed $r$-correlation $\left(r_{Z}\right)$ values. Pooled weighted $r_{Z}$ and $95 \%$ confidence intervals were calculated in an inverse-variance, random-effects model. Heterogeneity was assessed by the inconsistency index $\left(\mathrm{I}^{2}\right)$. Study quality was assessed on a checklist using items from validated quality appraisal guidelines. 1,195 records identified, 21 satisfied our inclusion criteria totalling 8,558 participants with mean age 52 \pm 4 years (range: 23-74). Most studies reported an inverse relationship between muscle tissue and arterial stiffness. Eight studies had data eligible for meta-analysis. Muscle tissue was inversely associated with pulse wave velocity in healthy individuals $\left[\mathrm{r}_{\mathrm{Z}}=-0.15\right.$ (95\%CI: $\left.0.24,-0.07) ; \mathrm{p}=0.0006 ; \mathrm{I}^{2}=85 \% ; \mathrm{n}=3,577\right]$ and in any population $\left[\mathrm{r}_{Z}=-0.18(-0.26,-0.10) ; \mathrm{p}<0.0001\right.$; $\left.\mathrm{I}^{2}=81 \% ; \mathrm{n}=3,930\right]$. In a leave-one-out sensitivity analysis, the results remained unchanged. Lower muscle tissue was associated with arterial stiffness. Studies were limited by cross-sectional design. Cardiovascular risk monitoring may be strengthened by screening for low muscle mass and maintaining muscle mass may be a primary prevention strategy.

Abstract word count: 202

Keywords: muscle; arterial stiffness; pulse wave velocity; meta-analysis

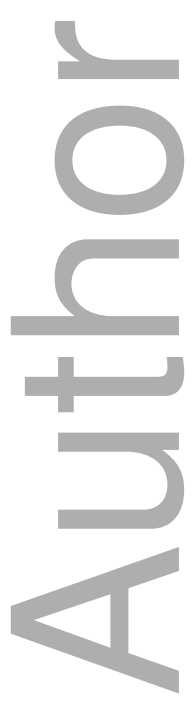




\section{$\underline{\text { Introduction }}$}

Sarcopenia describes the progressive loss of muscle mass and function. Whilst there are numerous consensus definitions to identify those with sarcopenia, it is widely accepted that the loss of muscle tissue during ageing can severely impact a person's health. Already, low muscle tissue has been associated with a number of important outcomes of ageing such as falls, fractures, osteoporosis, decreased quality of life and a loss of independence (1). Additionally, as muscle is the largest glucose utilising organ in the body, a loss of muscle tissue may also predispose to an altered glucose metabolism due to a loss in insulin sensitivity (2). Sarcopenia has also been associated with inflammation and eigarette smoking $(3,4)$. All the above mentioned factors are well-characterised causal influences on the development of cardiovascular (CV) disease, in particular atherosclerotic vascular disease. These observations have lent support to the hypothesis that sarcopenia may be associated with and is a marker of CV disease.

We now understand that much of the CV disease burden, particularly in older people, may be related to so-called "non-traditional" risk factors such as increased arterial stiffness and pulse pressure (5). Arterial stiffness describes the elastic properties of a blood vessel and its ability to expand and contract with pressure changes. Heavily calcified or atherosclerotic vessels change their elastic properties such that they become less compliant (stiffer) and are unable to cope effectively with haemodynamic stresses (6). Increased arterial stiffness augments cardiac workload which may predispose the individual to events such as myocardial infarction or stroke (7).

The gold standard for arterial stiffness measurement is determination of the carotid-femoral pulse wave velocity (PWV) but there is good agreement between other vascular sites such as the brachial-femoral (8). In less compliant vessels, the reflected waveform influences (increases) the systolic blood pressure and the extent of this increase is called the augmentation index (Aix). The pulse pressure (PP) describes the difference in the systolic and diastolic blood pressures. Consistently high PP is indicative of stiffness in the large elastic arteries, in particular the aorta. Overall, arterial stiffness is a simple, validated and independent predictor of cardiovascular morbidity and mortality in hypertension, type 2 diabetes, chronic kidney disease and in elderly populations (8).

Aside from observations that the risk factors for arterial stiffness are also predictive of sarcopenia, there are a number of mechanisms that may directly link the loss of muscle tissue with increased arterial stiffness including inflammatory cytokines, alterations in glucose handling and low physical activity. As such, there is growing observational evidence in humans that low muscle tissue is associated with increased arterial stiffness, however no study exists that has collated this work together and critically analysed the data. Therefore, the aim of this study was to determine if there was an inverse relationship between the amount of muscle tissue and arterial stiffness by way of a 
systematic review to survey the literature in this area and where possible, meta-analyse data to quantify the relationship.

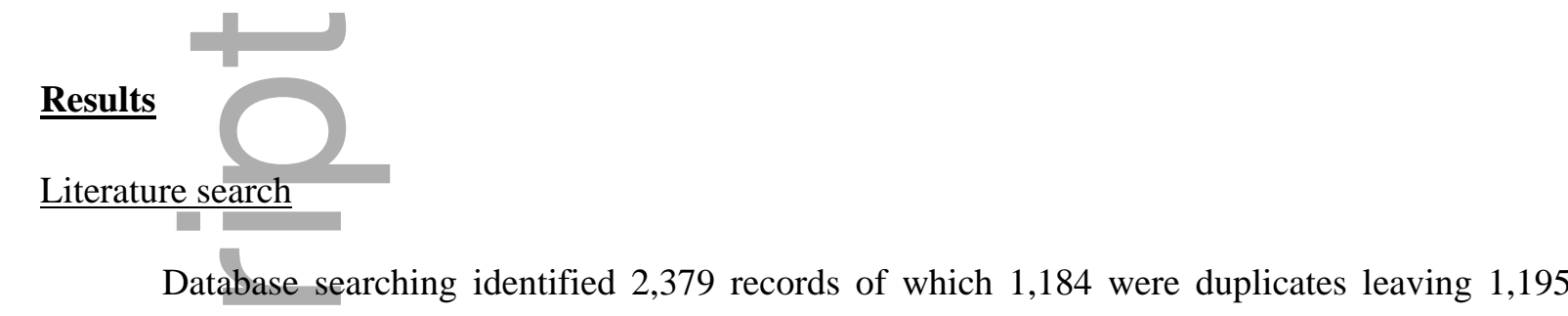
unique records for title/abstract screening. Following screening, 1,160 records were excluded primarily based on the fact the study did not assess an outcome of interest such as PWV, Aix or PP (records excluded on this basis, $\mathrm{n}=1,012$ ) which left 35 records for full-text review. Of these, a further 16 records were excluded mainly because the study did not relate a measure of muscle tissue with arterial stiffness $(n=10)$ leaving 19 records left. Snowballing techniques were used in conjunction with hand-searching to identify covert literature. At this stage, we identified a further two articles from hand searching reference lists of full-texts meaning a total of 21 records completely satisfied our inclusion criteria [Figure 1].

\section{Characteristics of study design and patient sampling}

Twenty studies were cross-sectional (9-28) and one study was prospective in design but still included baseline cross-sectional data (29). Fifteen studies (10, 11, 13-15, 17-20, 22-26, 28, 29) included a sample of healthy (older or younger) men and women. Three studies sampled participants with type 2 diabetes (T2D) $(9,25,26)$, one study selected participants with an ankle-brachial index $>0.9$ (27); one study selected participants on maintenance haemodialysis (HD) (16); one study selected young healthy astronaut trainees (12) and one study was conducted in patients undergoing occupational therapy for hemiparesis (21). Most studies were conducted in Japanese or Korean populations $(15-18,20-24,27)$. Other studies were conducted in USA (12, 19, 28, 29), Brazilian (11), Indian (9), French (10), British (13) and Dutch $(14,25,26)$ populations [Table 1].

\section{Quality assessment}

All but one study (12) achieved a quality score of at least 5 (out of 10). Six studies were deemed high quality achieving a score greater than $8(10,13,15,22,28,29)$. Commonly reported items were reporting of study aims and outcomes; reporting important confounding factors such as age, sex and BMI and measuring muscle tissue using validated methods. Inclusion/exclusion criteria, sample generalisability, adjustment analyses for multiple confounding factors, using validated methods to quantify arterial stiffness and identifying study limitations were variously reported (Supplementary table 1). 
Sample demographics

Study population varied from a minimum of 10 (12) to 2,272 (29). The average number of participants per study across the included literature was 387 and the total number of participants across all 21 included studies was 8,558. Three studies included only men $(10,12,20)$ and two studies included only women $(11,23)$ and there was an average of $51 \%$ males per study and $49 \%$ females per study. The lowest mean age was 23 years (19) and the highest was 74 years (29). Mean age for the study sample was not reported in three studies $(20,21,23)$ but these reported age ranges. Mean BMI ranged from a minimum $21.9 \mathrm{~kg} / \mathrm{m}^{2}$ (24) to a maximum of $30.2 \mathrm{~kg} / \mathrm{m}^{2}(9)$. Mean BMI for the sample was not reported in four studies $(12,20,21,23)$ [Table 1].

Assessment of muscle tissue

Most studies reported a measure of muscle mass $(9-15,17,18,21-26,28,29)$ (Table 3). Five studies reported measure of muscle cross-sectional area $(12,16,19,20,27)$. Muscle tissue was predominantly measured as either a whole body assessment $(10-13,15,21,22,29)$ or as an appendicular assessment $(9,14,17,18,23,24,28)$. Other studies measured muscle tissue or crosssectional area in specific body regions such as the thigh $(16,19,20,27)$ or trunk $(25,26,29)$. Most studies used radiological imaging to determine lean tissue including dual-energy x-ray absorptiometry (DXA) $(10,14,15,17,21,23-26,28,29)$, computed tomography (CT) $(12,16,17,20,27)$ or peripheral quantitative computed tomography (pQCT) (19). Other studies utilised bioelectrical impedance analysis (BIA) $(9,11,13,18,22)$. Assessment of sarcopenia was performed in seven studies $(11,15,17,22-24,29)$ where in all cases the operational definition consisted of skeletal/appendicular muscle mass relative to height-squared. Six of these studies utilised a cut-point for the definition, including the previously published Baumgartner $(30)$ definition $(17,29)$ and other user defined cut-points from a reference population $(11,15,23,24)$ [Table 2].

$\underline{\text { Assessment of arterial stiffness }}$

The majority of studies assessed PWV (9, 10, 13-17, 20-29) other studies assessed PP (11, 19), Aix $(18,19)$ and one study assessed leg compliance (12) [Table 3]. For studies assessing PWV, eight studies assessed brachial-ankle PWV (15-17, 20, 21, 23, 24, 27); seven studies assessed carotidfemoral PWV $(9,10,14,25,26,28,29)$ and one study assessed carotid-ankle PWV (22).

\section{$\underline{\text { Relationship between muscle tissue and arterial stiffness }}$}

Thirteen studies reported on the relationship between measures of muscle tissue and measures of arterial stiffness $(9-16,19-21,28,29)$ [Table 4]. The majority of these studies reported an rcorrelation statistic to describe the strength and direction of the relationship between the amount of muscle tissue and the measure of arterial stiffness $(9,11-13,15,16,19-21,28,29)$. Two studies provided a $\beta$-statistic to describe the direction of the relationship between muscle tissue and arterial 
stiffness $(10,11,14)$. For r-correlations relating muscle to PWV, the magnitude of the statistic ranged from - 0.02 (for the correlation between arm mass and PWV) (9) and -0.4795 (trunk mass and PWV) (28) in unadjusted analyses. In adjusted analyses, r-correlations ranged from -0.0082 (arm mass in women and PWV) (29) adjusting for multiple confounding factors, and -0.67 (whole body muscle mass) adjusting for age, bone mineral content, fat mass and intramuscular fat (21). In studies reporting r-correlations for PP one study reported a negative correlation (11) and another reported a positive correlation (19). Calf muscle area was negatively correlated with Aix after adjustment of height and sex in one study (19). In the study evaluating leg compliance, whole body lean mass was positively correlated with compliance whilst calf muscle area was negatively correlated (12). For studies reporting a $\beta$-statistic, all three studies reported a negative relationship between muscle mass, peripheral muscle mass and PWV and between skeletal muscle index (SMI) and PP (10, 11, 14). Three studies determined that the relationships were significant in men and not in women $(9,20,29)$ and another study determined thigh muscle area was significant in a sample of middle aged to elderly men but was non-significant when the group was stratified into those with type 2 diabetes mellitus and those that did not (20). Overall, only four studies did not report a significant relationship (10, 1214) between muscle tissue and arterial stiffness. There was a consistent trend across all studies for measures of muscle tissue at various sites in the body to be negatively related to arterial stiffness (mostly PWV) in unadjusted and multiple adjusted analyses.

\section{Meta-analysis of studies reporting correlation statistics}

The most complete and consistent data related to the correlation between muscle tissue with PWV which included data from eight studies $(9,13,15,16,20,21,28,29)$. These data were synthesised into a meta-analysis model. In studies enrolling only healthy participants, muscle tissue was inversely and significantly correlated with PWV $\left(r_{Z}=-0.15\right.$ and $95 \%$ confidence interval $=-0.24$, $-0.07 ; \mathrm{p}=0.0006, \mathrm{n}=3577$, five studies) with substantial heterogeneity $\left(\mathrm{I}^{2}=85 \%\right)$ [Figure 2]. When data was included from studies enrolling participants from specific patient groups, the results remained similar PWV $\left(\mathrm{r}_{\mathrm{Z}}=-0.18 ;-0.26,-0.10 ; \mathrm{p}<0.0001, \mathrm{n}=3930\right.$, eight studies; $\left.\mathrm{I}^{2}=81 \%\right)$ [Figure 3]. In sensitivity analyses [Table 5], considering only studies with a mean sample age of 60 years there was data available from two studies $(20,29)$ and there was a significant negative relationship between muscle tissue and PWV $\left(r_{Z}=-0.12 ; 95 \%\right.$ CI: $\left.-0.22,-0.01 ; p=0.02, I^{2}=85 \%\right)$. Similarly, in studies whose mean sample age was $<60$ years, there was present a significant negative relationship between muscle tissue and PWV $\left(r_{Z}=-0.22 ; 95 \%\right.$ CI: $\left.-0.35,-0.09 ; \mathrm{p}=0.0009, \mathrm{I}^{2}=72 \%\right)$. When the studies were stratified according the imaging modality employed, results were similar whether DXA $\left(r_{Z}=-0.19 ; 95 \%\right.$ CI: $\left.-0.32,-0.07 ; p=0.002, I^{2}=89 \%\right)$ or other modalities $\left(r_{Z}=-0.16\right.$; 95\% CI: -0.22 , $0.10 ; \mathrm{p}<0.0001, \mathrm{I}^{2}=42 \%$, fixed model applied) were used. Finally, in order to examine the potential effect the site of muscle tissue assessment, we stratified the studies according to whether the whole body muscle tissue was assessed $\left(r_{\mathrm{Z}}=-0.11 ; 95 \% \mathrm{CI}:-0.20,-0.02 ; \mathrm{p}=0.02, \mathrm{I}^{2}=82 \%\right)$ or regional 
muscle tissue $\left(\mathrm{r}_{\mathrm{Z}}=-0.24 ; 95 \% \mathrm{CI}:-0.34,-0.13 ; \mathrm{p}<0.0001, \mathrm{I}^{2}=59 \%\right)$ and found results similar to other analyses. Finally, we performed a leave-one-out sensitivity analysis and omission of any one study did not alter the final result [Table 6].

\section{$\underline{\text { Discussion }}$}

Sarcopenia, the progressive loss of muscle mass and function, has been associated with CV disease. Arterial stiffness is emerging as an important $\mathrm{CV}$ risk factor and given the common risk factors between sarcopenia and arterial stiffness observational studies have demonstrated the concomitant incidence of low muscle mass with increased arterial stiffness. This systematic review and meta-analysis collated results from observational studies which collectively demonstrate that low muscle tissue is consistently associated with increased arterial stiffness. Whilst heterogeneity in terms of study design, population samples and methodology may bias and limit the interpretation of the quantitative meta-analysis component of this review; given the consistent inverse relationship seen across all studies included in this review, there is a biological interaction which may not necessarily be captured statistically due to heterogeneity. For this reason, the present study adds value to the literature as it highlights the need to develop high quality prospective studies conducted in healthy populations using gold-standard techniques to determine if low muscle tissue is both predictive and causative of arterial stiffness.

The causal biological link between low muscle tissue and increased arterial stiffness is only assumed given these data were largely cross-sectional (only one study identified was longitudinal) (29). Therefore, the possible mechanisms by which low muscle tissue may contribute to increased arterial stiffness are unclear. It has also been suggested that increased arterial stiffness proceeds the loss of muscle tissue as heavily calcified and stiff blood vessels may restrict nutrient supply to muscle tissue causing its atrophy. However, there exists a number of pathways common to both muscle loss and increased arterial stiffness including insulin resistance, oxidative stress and inflammation which may offer mechanism insights (31).

Muscle is the largest site of glucose disposal and its loss can impair glucose metabolism which may result in insulin insensitivity/resistance (32). Several human studies suggest that impaired glucose tolerance and insulin resistance adversely affects the mechanical properties of arteries (33). The mechanisms that lead to adverse vascular changes are thought to occur through oxidative stress and endothelial damage. In a Korean cohort, PWV positively correlated with insulin and had higher concentrations of isoprostane 8-epi PGF2 $\alpha$ (an oxidative stress marker) in those with impaired fasting glucose (34). Further, in a hypertensive older adult sample, statin therapy improved the oxidative markers $N$-(epsilon)-carboxymethyl-lysine, Von Willebrand factor and copper/zinc-containing superoxide dismutase. These improvements were correlated with improvements in brachial-ankle 
PWV suggesting that oxidative stress precedes increases in arterial stiffness possibly by increasing reactive oxide species (35). Taken together, these studies indicate that impaired glucose metabolism and alterations in oxidative stress at the vascular endothelium directly contribute to vessel compliance and offer a link between how muscle biology may influence the development of arterial stiffness.

Chronic inflammation is another well described mechanism of muscle loss. Inflammatory mediators such as interleukin-6 (IL-6), tumour necrosis factor- $\alpha$ and C-reactive protein can directly affect muscle catabolism and may also act indirectly by lowering growth hormones (36). These inflammatory pathways are shared in the pathogenesis of arterial stiffening. Aortic PWV correlated positively with a number of inflammatory markers such as IL-6, transforming growth factor- $\beta 1$, and white blood cell count in dialysis patients (37). Further, osteocalcin, a marker of bone formation produced by osteoblasts, was negatively correlated with aortic PWV after multiple regression. Given osteocalcin's role in bone remodelling, this finding suggests bone biology may influence arterial stiffness and indeed elevated arterial stiffness has been demonstrated in postmenopausal women with osteoporosis (38).

A number of important limitations of the included studies could contribute to the risk of bias. Firstly, the majority of studies were cross-sectional in design. Given that several of these did not adjust for multiple confounders $(9,16,28)$, there may be residual confounding in our analysis. Secondly, some studies had small sample sizes [eg. $n=10$ (12)] or the cohort was from a specific patient population [eg. hemiparesis in-patients (21)] and thus their results may not be generalisable. Thirdly, the use of medications was poorly reported and this may potentially impact on blood pressure, blood lipid profile and other risk factors of arterial stiffening. Few studies reported on the amount of objectively measured physical activity undertaken by study participants. This is significant because physical activity is important in maintaining muscle mass and decreasing arterial stiffness by augmenting oxidative stress markers, particularly in older age $(39,40)$. Finally, for stiffness assessment some studies used oscillometric methods and others employed tonometric methods and similarly there were different methods used to quantify muscle tissue (eg. DXA and CT). There is good agreement between these methods to quantify both arterial stiffness (41) and muscle tissue (42) though these different methods employed across this literature reflects the lack of a standardised approach to measuring arterial compliance and muscle tissue. In attempt to overcome this potential limitation, our sensitivity analyses found similar results when studies were stratified by imaging modality.

The limitations of the present study were that we used aggregate data from a small number of studies. This limited our ability to perform stratified analyses from individual patient data according important confounding factors rather than study-level variables. We also grouped together a 
heterogeneous sample of studies (Japanese, European and North American populations). Overall, we attempted to overcome the obvious heterogeneity in study methods by employing random-effects models which offer more conservative effect estimates and in performing a number of sensitivity analyses restricting each analysis to studies of similar methodology or population sample. Specifically, our study may be limited by crude measures of body composition which may not accurately reflect the degree of muscle loss and disability burden across diverse populations (43). Most data were from cross-sectional studies which do not imply causation. We did not restrict our search criteria to exclude interventional studies or other observational studies. Thus, our study highlights the need for more prospective investigations as cross-sectional relationships do not accurately reflect low muscle tissue. We have considered different measures of muscle tissue to all indicate low muscle mass. This is not entirely accurate as differences in muscle cross-sectional area may reflect changes in muscle fibre size as well as fibre atrophy (44). We have also considered different vascular sites such as brachial-ankle and carotid-femoral PWV as measures of arterial stiffness. However, there is good agreement between these measure and we reasoned that in order to maximise the statistical power of our analyses, it was prudent to consider these measurements together rather than conduct separate brachial-ankle or carotid-femoral PWV analyses. Overall, these differences in study methodology highlight the need for a more standardised approach which would ideally involve measurement of aortic PWV and conducted in healthy individuals.

In conclusion, we identified numerous observational studies that reported on the correlation or association of muscle tissue and arterial stiffness. These results suggest that there was a consistent inverse relationship between the amount of muscle tissue and the level of arterial stiffness across diverse population groups. This finding was consistent across several sensitivity analysis accounting for important risk factors of muscle loss and arterial stiffness. Given the lack of prospective data, determination of whether low muscle mass predicts increases in arterial stiffness over time is warranted. Further, it remains to be seen whether improving muscle mass concurrently improves arterial stiffness. Since, arterial stiffness is predictive of CV mortality and events and hence these events could accelerate the transition of people with low muscle mass to greater disability and mortality, this systematic review and meta-analysis suggests it may be useful to consider the cardiovascular health of people with low muscle mass.

\section{Methods:}

$\underline{\text { Study focus }}$ 
This study was conducted in accordance with the guidelines outlined in the MOOSE statement (Meta-analysis Of Observational Studies in Epidemiology) (45). Studies were eligible if they were observational in design (cross-sectional or longitudinal/prospective), reported a measure of muscle tissue, reported a measure of arterial stiffness and performed a statistical assessment of the relationship between these measures in order to determine the linearity between these measures. Specific exclusion criteria were non-observational studies, animal or cell-based studies, reviews and other meta-analyses and individual case reports. We restricted our analysis to observational studies only as we reasoned that we wanted to be able to establish the natural incidence of both low muscle tissue and increased arterial stiffness. Interventional studies could, depending on the type intervention, potentially alter measures of both arterial stiffness and muscle tissue and thus affect the association between these measures.

\section{$\underline{\text { Literature search }}$}

Records were retrieved by searching MEDLINE (archives from 1966-2016) and EMBASE (1946-2016) databases. Records were identified on the $23^{\text {rd }}$ of February 2016 using a search string detailed in Supplementary Table 1. Titles and abstracts of identified records were screened by a single reviewer (AJR). Reference lists were manually scanned by hand searching. Following title and abstract screening, full text articles were interrogated to determine eligibility for inclusion. For fulltexts unavailable publically, attempts were made to obtain these or specific data directly from the authors to ensure eligibility.

\section{Data extraction}

Data capture was performed independently by two reviewers (AJR, MNK) with the aid of a data extraction template. The information captured during data extraction was: the name of the first author, year of publication, study design, sample demographics, measurement of muscle tissue and arterial stiffness, statistical analyses employed and study limitations. These data were then tabulated into a format that enabled comparison of relevant study details. Data relating to the relationship between muscle tissue and arterial stiffness were also tabulated.

Quality assessment

Further to data extraction, we performed a quality assessment of studies included in the systematic review. As no standardised quality assessment checklist exists for observational studies reporting on the association between muscle tissue and arterial stiffness, we designed a ten-point semi-quantitative questionnaire using preferred reporting items from MOOSE to judge quality of included studies. Items in our checklist related to study design, generalisability, outcome measurement, statistical analysis and limitations. Items were checked as either "yes", "no" or 
"unclear" and a score of greater than or equal to 8 (yes responses out of 10) was deemed high quality; scores 5-7 were good quality and scores less than or equal to 4 were poor quality (Specific questions are provided in Supplementary Table 2).

\section{$\underline{\text { Statistical operations }}$}

Meta-analysis eligibility:

Studies were included for meta-analysis if they first satisfied the inclusion and exclusion criteria for systematic review and then reported correlation or association statistics (for example Pearson's $r$ correlation coefficient, standardised $(\beta)$ coefficient, $\mathrm{R}^{2}$ correlation coefficient or odds ratios) in assessing the relationship between muscle tissue and arterial stiffness. Studies were excluded from meta-analysis, but still kept in the qualitative review, if they reported only descriptive statistics for measures of arterial stiffness according to groups defined on the basis of the amount of muscle tissue (eg. above or below the median amount of muscle tissue). For studies that reported on multiple sites of muscle tissue (eg. leg or arm muscle mass) preference for inclusion in meta-analysis dataset was arbitrarily first given to whole body, then appendicular, then leg, then arm, then trunk measures.

\section{Meta-analysis:}

Data was first tabulated into a format that enabled visualisation of group data. In order to pool correlation statistics together, we converted r-correlation coefficients into to the Fisher's z scale using the Fisher's $Z$ transformation: $Z=0.5 \times \ln \left(\frac{1+r}{1-r}\right)$ and calculated the standard error: $S E=\sqrt{ }\left(\frac{1}{n-3}\right)$ (46). The Fisher's Z score and its variance are used in the analysis. These data were then synthesised into an inverse-variance model to determine the pooled weighted $\mathrm{r}$ correlation and $95 \%$ confidence interval. Heterogeneity was determined by the inconsistency statistic $\left(\mathrm{I}^{2}\right)$ where a DerSimonian and Laird random-effects model was applied if $\mathrm{I}^{2}$ was greater than $50 \%$. A number of sensitivity analyses were performed in order to examine the possible effects of factors that may contribute to muscle loss and arterial stiffness. To assess the effect of age, we divided our analysis into studies with a mean age of $\geq 60 \mathrm{y}$ ears and studies with a mean age $<60$ years and performed the same operations as above. Similarly, though there is good agreement between imaging modalities, to account for potential differences in lean mass measurements we stratified the analysis separating those studies who used DXA and those who used another modality. Finally, whole body muscle mass assessment would best reflect low muscle mass though some studies assessed regional muscle mass such as thigh muscle mass, therefore to investigate the potential effect of imaging site we stratified the analysis into whole body muscle mass assessment and regional muscle mass assessment. Additionally we performed a leave-one-out sensitivity analysis were, sequentially, each study was excluded from the meta-analysis 
model in order to determine if the summary effect was overly influenced by any single study (which may be the case for a large study group with smaller studies). All statistical operations were performed using RevMan v5.3 software (The Nordic Cochrane Centre, The Cochrane Collaboration 2012) and in consultation with a statistician (MNK).

Acknowledgements

The authors would like to thank Dr. Terry Neeman from the Australian National University for her advice on the statistical operations.

Author contributions

AJR designed the study, performed literature searches, data extraction, data analysis, constructed tables and figures and wrote the first draft. MNK Performed data extraction and data analysis. VS provided expert advice on arterial stiffness. PE provided expert advice on muscle biology. DS provided expert advice on muscle biology, contributed to data analysis and table/figure presentation and contributed to manuscript development. All authors reviewed the final draft

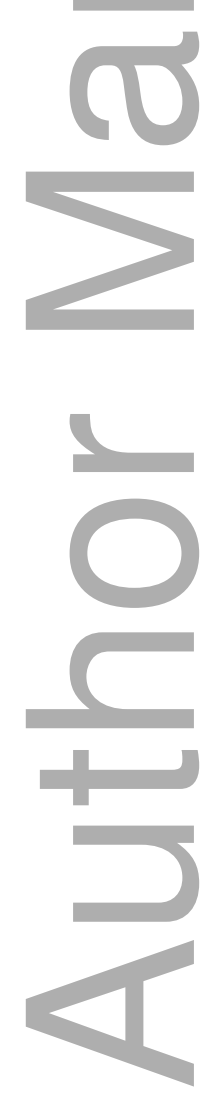

References 
1. Scott D, Daly RM, Sanders KM, Ebeling PR. Fall and Fracture Risk in Sarcopenia and Dynapenia With and Without Obesity: the Role of Lifestyle Interventions. Current osteoporosis reports. 2015;13(4):235-44.

2. Cleasby $\mathrm{ME}$, Jamieson $\mathrm{P}$, Atherton PJ. Insulin resistance and sarcopenia: mechanistic links between common co-morbidities. The Journal of endocrinology. 2016.

3. Petersen AM, Magkos F, Atherton P, Selby A, Smith K, Rennie MJ, et al. Smoking impairs muscle protein synthesis and increases the expression of myostatin and MAFbx in muscle. American journal of physiology Endocrinology and metabolism. 2007;293(3):E843-8.

4. Roubenoff R. Physical activity, inflammation, and muscle loss. Nutrition reviews. 2007;65(12 Pt 2):S208-12.

5. Willum-Hansen T, Staessen JA, Torp-Pedersen C, Rasmussen S, Thijs L, Ibsen H, et al. Prognostic value of aortic pulse wave velocity as index of arterial stiffness in the general population. Circulation. 2006;113(5):664-70.

6. Frost ML, Grella R, Millasseau SC, Jiang BY, Hampson G, Fogelman I, et al. Relationship of calcification of atherosclerotic plaque and arterial stiffness to bone mineral density and osteoprotegerin in postmenopausal women referred for osteoporosis screening. Calcified tissue international. 2008;83(2):112-20.

7. Steppan J, Barodka V, Berkowitz DE, Nyhan D. Vascular stiffness and increased pulse pressure in the aging cardiovascular system. Cardiology research and practice. 2011;2011:263585.

8. Laurent S, Cockcroft J, Van Bortel L, Boutouyrie P, Giannattasio C, Hayoz D, et al. Expert consensus document on arterial stiffness: methodological issues and clinical applications. European heart journal. 2006;27(21):2588-605.

9. Anoop S, Misra A, Bhardwaj S, Gulati S. High body fat and low muscle mass are associated with increased arterial stiffness in Asian Indians in North India. Journal of diabetes and its complications. 2015;29(1):38-43.

10. Benetos A, Zervoudaki A, Kearney-Schwartz A, Perret-Guillaume C, Pascal-Vigneron V, Lacolley $P$, et al. Effects of lean and fat mass on bone mineral density and arterial stiffness in elderly men. Osteoporosis international : a journal established as result of cooperation between the European Foundation for Osteoporosis and the National Osteoporosis Foundation of the USA. 2009;20(8):1385-91.

11. Coelho Junior HJ, Aguiar Sda S, Goncalves Ide O, Sampaio RA, Uchida MC, Moraes MR, et al. Sarcopenia Is Associated with High Pulse Pressure in Older Women. Journal of aging research. 2015;2015:109824.

This article is protected by copyright. All rights reserved 
12. Convertino VA, Doerr DF, Flores JF, Hoffler GW, Buchanan P. Leg size and muscle functions associated with leg compliance. Journal of applied physiology (Bethesda, Md : 1985). 1988;64(3):1017-21.

13. Corden B, Keenan NG, de Marvao AS, Dawes TJ, Decesare A, Diamond T, et al. Body fat is associated with reduced aortic stiffness until middle age. Hypertension. 2013;61(6):1322-7.

14. Ferreira I, Snijder MB, Twisk JW, van Mechelen W, Kemper HC, Seidell JC, et al. Central fat mass versus peripheral fat and lean mass: opposite (adverse versus favorable) associations with arterial stiffness? The Amsterdam Growth and Health Longitudinal Study. The Journal of clinical endocrinology and metabolism. 2004;89(6):2632-9.

15. Hong HC, Hwang SY, Choi HY, Yoo HJ, Seo JA, Kim SG, et al. Relationship between sarcopenia and nonalcoholic fatty liver disease: the Korean Sarcopenic Obesity Study. Hepatology (Baltimore, Md). 2014;59(5):1772-8.

16. Kato A, Ishida J, Endo Y, Takita T, Furuhashi M, Maruyama Y, et al. Association of abdominal visceral adiposity and thigh sarcopenia with changes of arteriosclerosis in haemodialysis patients. Nephrology, dialysis, transplantation : official publication of the European Dialysis and Transplant Association - European Renal Association. 2011;26(6):1967-76.

17. Kim TN, Park MS, Lim KI, Yang SJ, Yoo HJ, Kang HJ, et al. Skeletal muscle mass to visceral fat area ratio is associated with metabolic syndrome and arterial stiffness: The Korean Sarcopenic Obesity Study (KSOS). Diabetes research and clinical practice. 2011;93(2):285-91.

18. Lee SW, Youm Y, Kim CO, Lee WJ, Choi W, Chu SH, et al. Association between skeletal muscle mass and radial augmentation index in an elderly Korean population. Archives of gerontology and geriatrics. 2014;59(1):49-55.

19. Loenneke JP, Fahs CA, Heffernan KS, Rossow LM, Thiebaud RS, Bemben MG. Relationship between thigh muscle mass and augmented pressure from wave reflections in healthy adults. European journal of applied physiology. 2013;113(2):395-401.

20. Ochi M, Kohara K, Tabara Y, Kido T, Uetani E, Ochi N, et al. Arterial stiffness is associated with low thigh muscle mass in middle-aged to elderly men. Atherosclerosis. 2010;212(1):327-32.

21. Okabe R, Inaba M, Sakai S, Ishimura E, Moriguchi A, Shoji T, et al. Increased arterial stiffening and thickening in the paretic lower limb in patients with hemiparesis. Clinical science (London, England : 1979). 2004;106(6):613-8.

22. Sampaio RA, Sewo Sampaio PY, Yamada M, Yukutake T, Uchida MC, Tsuboyama T, et al. Arterial stiffness is associated with low skeletal muscle mass in Japanese community-dwelling older adults. Geriatrics \& gerontology international. 2014;14 Suppl 1:109-14. 
23. Sanada K, lemitsu M, Murakami H, Gando Y, Kawano H, Kawakami R, et al. Adverse effects of coexistence of sarcopenia and metabolic syndrome in Japanese women. European journal of clinical nutrition. 2012;66(10):1093-8.

24. Sanada K, Miyachi M, Tanimoto M, Yamamoto K, Murakami H, Okumura S, et al. A crosssectional study of sarcopenia in Japanese men and women: reference values and association with cardiovascular risk factors. European journal of applied physiology. 2010;110(1):57-65.

25. Snijder MB, Flyvbjerg A, Stehouwer CD, Frystyk J, Henry RM, Seidell JC, et al. Relationship of adiposity with arterial stiffness as mediated by adiponectin in older men and women: the Hoorn Study. European journal of endocrinology / European Federation of Endocrine Societies. 2009;160(3):387-95.

26. Snijder MB, Henry RM, Visser M, Dekker JM, Seidell JC, Ferreira I, et al. Regional body composition as a determinant of arterial stiffness in the elderly: The Hoorn Study. Journal of hypertension. 2004;22(12):2339-47.

27. Tabara $\mathrm{Y}$, Igase M, Kido T, Ochi N, Miki T, Kohara K. Composition of lower extremity in relation to a high ankle-brachial index. Journal of hypertension. 2009;27(1):167-73.

28. Wohlfahrt P, Somers VK, Sochor O, Kullo I, Jean N, Lopez-Jimenez F. Influence of body fatness distribution and total lean mass on aortic stiffness in nonobese individuals. American journal of hypertension. 2015;28(3):401-8.

29. Abbatecola AM, Chiodini P, Gallo C, Lakatta E, Sutton-Tyrrell K, Tylavsky FA, et al. Pulse wave velocity is associated with muscle mass decline: Health ABC study. Age. 2012;34(2):469-78.

30. Baumgartner RN, Koehler KM, Gallagher D, Romero L, Heymsfield SB, Ross RR, et al. Epidemiology of sarcopenia among the elderly in New Mexico. American journal of epidemiology. 1998;147(8):755-63.

31. Zieman SJ, Melenovsky V, Kass DA. Mechanisms, pathophysiology, and therapy of arterial stiffness. Arteriosclerosis, thrombosis, and vascular biology. 2005;25(5):932-43.

32. Aleman-Mateo H, Lopez Teros MT, Ramirez FA, Astiazaran-Garcia H. Association between insulin resistance and low relative appendicular skeletal muscle mass: evidence from a cohort study in community-dwelling older men and women participants. The journals of gerontology Series $A$, Biological sciences and medical sciences. 2014;69(7):871-7.

33. Ikonomidis I, Lambadiari V, Pavlidis G, Koukoulis C, Kousathana F, Varoudi M, et al. Insulin resistance and acute glucose changes determine arterial elastic properties and coronary flow reserve in dysglycaemic and first-degree relatives of diabetic patients. Atherosclerosis. 2015;241(2):455-62.

34. Paik JK, Kim M, Kwak JH, Lee EK, Lee SH, Lee JH. Increased arterial stiffness in subjects with impaired fasting glucose. Journal of diabetes and its complications. 2013;27(3):224-8. 
35. Wang J, Xu J, Zhou C, Zhang Y, Xu D, Guo Y, et al. Improvement of arterial stiffness by reducing oxidative stress damage in elderly hypertensive patients after 6 months of atorvastatin therapy. Journal of clinical hypertension (Greenwich, Conn). 2012;14(4):245-9.

36. Taekema DG, Ling CH, Blauw GJ, Meskers CG, Westendorp RG, de Craen AJ, et al. Circulating levels of IGF1 are associated with muscle strength in middle-aged- and oldest-old women. European journal of endocrinology / European Federation of Endocrine Societies. 2011;164(2):189-96.

37. Krzanowski $M$, Janda $K$, Dumnicka $P$, Dubiel $M$, Stompor $M$, Kusnierz-Cabala $B$, et al. Relationship between aortic pulse wave velocity, selected proinflammatory cytokines, and vascular calcification parameters in peritoneal dialysis patients. Journal of hypertension. 2014;32(1):142-8.

38. Sumino H, Ichikawa S, Kasama S, Takahashi T, Kumakura H, Takayama $Y$, et al. Elevated arterial stiffness in postmenopausal women with osteoporosis. Maturitas. 2006;55(3):212-8.

39. Hughes VA, Frontera WR, Roubenoff R, Evans WJ, Singh MAF. Longitudinal changes in body composition in older men and women: role of body weight change and physical activity. The American journal of clinical nutrition. 2002;76(2):473-81.

40. Tanaka H, Dinenno FA, Monahan KD, Clevenger CM, DeSouza CA, Seals DR. Aging, habitual exercise, and dynamic arterial compliance. Circulation. 2000;102(11):1270-5.

41. Wassertheurer S, Kropf J, Weber T, van der Giet M, Baulmann J, Ammer M, et al. A new oscillometric method for pulse wave analysis: comparison with a common tonometric method. J Hum Hypertens. 2010;24(8):498-504.

42. XuL, Cheng X, Wang J, Cao Q, Sato T, Wang M, et al. Comparisons of Body-Composition Prediction Accuracy: A Study of 2 Bioelectric Impedance Consumer Devices in Healthy Chinese Persons Using DXA and MRI as Criteria Methods. Journal of Clinical Densitometry.14(4):458-64.

43. Chen LK, Liu LK, Woo J, Assantachai P, Auyeung TW, Bahyah KS, et al. Sarcopenia in Asia: consensus report of the Asian Working Group for Sarcopenia. Journal of the American Medical Directors Association. 2014;15(2):95-101.

44. Lexell J. Human aging, muscle mass, and fiber type composition. The journals of gerontology Series A, Biological sciences and medical sciences. 1995;50 Spec No:11-6.

45. Stroup DF, Berlin JA, Morton SC, Olkin I, Williamson GD, Rennie D, et al. Meta-analysis of observational studies in epidemiology: a proposal for reporting. Meta-analysis Of Observational Studies in Epidemiology (MOOSE) group. Jama. 2000;283(15):2008-12.

46. Fisher RA. Frequency Distribution of the Values of the Correlation Coefficient in Samples from an Indefinitely Large Population. Biometrika. 1915;10(4):507-21.

This article is protected by copyright. All rights reserved 
Table 1. Study details and sample demographics

\begin{tabular}{|c|c|c|c|c|c|c|c|c|c|c|}
\hline Study \& Year & Design & Sample & Country & $\mathrm{n}$ & $\mathrm{M}-\mathrm{F} \%$ & Age & BMI $\left(\mathrm{kg} / \mathrm{m}^{2}\right)$ & $\mathrm{T} 2 \mathrm{D}$ & SBP & Inclusion-Exclusion criteria \\
\hline $\begin{array}{l}\text { Abbatecola } \\
2012(32)\end{array}$ & Prospective & $\begin{array}{l}\text { Community } \\
\text { dwelling older adults }\end{array}$ & USA & 2272 & $50-50$ & 73.7 & 27.2 & 14.30 & 134.8 & $\begin{array}{l}\text { No difficulty walking quarter-mile, climbing } 10 \\
\text { steps and performing basic activities of living. } \\
\text { Free from life-threatening illness }\end{array}$ \\
\hline $\begin{array}{l}\text { Anoop } 2015 \\
\text { (12) }\end{array}$ & $\begin{array}{l}\text { Cross- } \\
\text { sectional }\end{array}$ & $\mathrm{T} 2 \mathrm{D}$ & India & 168 & $65-35$ & 50.3 & 30.15 & 100 & 128.7 & $\mathrm{n} / \mathrm{r}$ or unclear \\
\hline $\begin{array}{l}\text { Benetos } 2009 \\
\text { (13) }\end{array}$ & $\begin{array}{l}\text { Cross- } \\
\text { sectional }\end{array}$ & $\begin{array}{l}\text { Community } \\
\text { dwelling older men }\end{array}$ & France & 169 & $100-0$ & 69.3 & 27.3 & $\mathrm{n} / \mathrm{r}$ & 137 & $\begin{array}{l}\text { I: }>60 y \text {, elegible for DXA, no osteoporosis, no } \\
\text { CVD, no atrial fibrillation }\end{array}$ \\
\hline $\begin{array}{l}\text { Coelho } 2015 \\
\text { (14) }\end{array}$ & $\begin{array}{l}\text { Cross- } \\
\text { sectional }\end{array}$ & $\begin{array}{l}\text { Community } \\
\text { dwelling older adults }\end{array}$ & Brazil & 130 & $0-100$ & 64.3 & 26.85 & 4.85 & 140.4 & $\begin{array}{l}\text { I: >60y; E: HRT, psychotropic drugs, CVD, } \\
\text { pulmonary disease, psychiatric disease, } \\
\text { musculoskeletal disorders, at risk of falls }\end{array}$ \\
\hline $\begin{array}{l}\text { Convertino } \\
1988(15)\end{array}$ & Sectional & Young healthy men & USA & 10 & $100-0$ & 36 & $\mathrm{n} / \mathrm{r}$ & $\mathrm{n} / \mathrm{r}$ & $\mathrm{n} / \mathrm{r}$ & E: Taking medications, non-smoking \\
\hline $\begin{array}{l}\text { Corden } 2013 \\
\text { (16) }\end{array}$ & $\begin{array}{l}\text { Cross- } \\
\text { sectional }\end{array}$ & $\begin{array}{l}\text { Community } \\
\text { dwelling adults }\end{array}$ & UK & 221 & $43-57$ & 40.3 & 25.5 & $\mathrm{n} / \mathrm{r}$ & 120.4 & $\begin{array}{l}\text { E: CVD, meds for hypertension, DM or } \\
\text { cholesterol, pregnant or lactating women }\end{array}$ \\
\hline $\begin{array}{l}\text { Ferreira } 2004 \\
(17)\end{array}$ & $\begin{array}{l}\text { Cross- } \\
\text { sectional }\end{array}$ & $\begin{array}{l}\text { Community } \\
\text { dwelling adults }\end{array}$ & Netherlands & 336 & $48-52$ & 35.6 & 24.04 & $\mathrm{n} / \mathrm{r}$ & 116.2 & $\mathrm{n} / \mathrm{r}$ or unclear \\
\hline $\begin{array}{l}\text { Hong } 2014 \\
\text { (18) }\end{array}$ & Sectional & $\begin{array}{l}\text { Community } \\
\text { dwelling adults }\end{array}$ & Korea & 452 & $38-62$ & 53 & 24.19 & $\mathrm{n} / \mathrm{a}$ & 121.9 & $\begin{array}{l}\text { I: No DM, CVD, hypertension, malignant } \\
\text { disease, renal disease, hepatic disease. No meds, } \\
\text { alcohol consumption }>140 \mathrm{~g} / \text { week, Hepatitis B or } \\
\mathrm{C} \text {, herbal medication use in previous } 6 \text { months }\end{array}$ \\
\hline $\begin{array}{l}\text { Kato } 2011 \\
\text { (19) }\end{array}$ & $\begin{array}{l}\text { Cross- } \\
\text { sectional }\end{array}$ & HD & Japan & 161 & $70-30$ & 61 & 20.7 & $\mathrm{n} / \mathrm{r}$ & 138 & E: $>80 y$, advanced cancer \\
\hline $\begin{array}{l}\text { Kim } 2011 \\
(20)\end{array}$ & $\begin{array}{l}\text { Cross- } \\
\text { sectional }\end{array}$ & $\begin{array}{l}\text { Community } \\
\text { dwelling adults }\end{array}$ & Korea & 510 & $32-68$ & 53.6 & 24.38 & $\mathrm{n} / \mathrm{a}$ & 121.8 & $\begin{array}{l}\text { I: No DM, CVD, hypertension, malignant } \\
\text { disease, renal disease, hepatic disease. No meds, } \\
\text { alcohol consumption }>140 \mathrm{~g} / \text { week, Hepatitis B or } \\
\text { C, herbal med use in previous } 6 \text { months }\end{array}$ \\
\hline
\end{tabular}

This article is protected by copyright. All rights reserved 


\begin{tabular}{|c|c|c|c|c|c|c|c|c|c|c|}
\hline Lee 2014 (21) & $\begin{array}{l}\text { Cross- } \\
\text { sectional }\end{array}$ & $\begin{array}{l}\text { Community } \\
\text { dwelling older adults }\end{array}$ & Korea & 428 & $42-58$ & 70.9 & 24 & $\mathrm{n} / \mathrm{r}$ & 132 & E: patients with incomplete testing records \\
\hline $\begin{array}{l}\text { Loenneke } \\
2013(22)\end{array}$ & $\begin{array}{l}\text { Cross- } \\
\text { sectional }\end{array}$ & $\begin{array}{l}\text { Community } \\
\text { dwelling adults }\end{array}$ & USA & 27 & $48-52$ & 23 & 24.4 & $\mathrm{n} / \mathrm{r}$ & 118 & I: non-smoker, no CVD or metabolic disturbance \\
\hline $\begin{array}{l}\text { Ochi } 2010= \\
(23)\end{array}$ & $\begin{array}{l}\text { Cross- } \\
\text { sectional }\end{array}$ & $\begin{array}{l}\text { Community } \\
\text { dwelling middle age } \\
\text { to older adults }\end{array}$ & Japan & 496 & $100-0$ & $\mathrm{n} / \mathrm{r}$ & $\mathrm{n} / \mathrm{r}$ & $\mathrm{n} / \mathrm{r}$ & $\mathrm{n} / \mathrm{r}$ & I: free of cerebrovascular events \\
\hline $\begin{array}{l}\text { Okabe } 2004 \\
(24)\end{array}$ & $\begin{array}{l}\text { Cross- } \\
\text { sectional }\end{array}$ & OT in-patients & Japan & 24 & $58-42$ & $\mathrm{n} / \mathrm{r}$ & $\mathrm{n} / \mathrm{r}$ & $\mathrm{n} / \mathrm{r}$ & $\mathrm{n} / \mathrm{r}$ & $\begin{array}{l}\text { I: Had cerebrovascular event in previous } 3 \\
\text { months, physically stable }\end{array}$ \\
\hline $\begin{array}{l}\text { Sampaio } 2014 \\
\text { (25) }\end{array}$ & Cross- & $\begin{array}{l}\text { Community } \\
\text { dwelling older adults }\end{array}$ & Japan & 175 & $48-52$ & 73.6 & 23.02 & 11.7 & $\stackrel{\wedge}{41.30}$ & $\begin{array}{l}\text { I: >65y, independent. E: mild cognitive } \\
\text { impairment, uncontrolled CVD/metabolic } \\
\text { disease, orthopaedic conditions, risk of falls }\end{array}$ \\
\hline $\begin{array}{l}\text { Sanada } 2012 \\
(26)\end{array}$ & $\begin{array}{l}\text { Cross- } \\
\text { sectional }\end{array}$ & $\begin{array}{l}\text { Community } \\
\text { dwelling older } \\
\text { women }\end{array}$ & Japan & 533 & $0-100$ & $30-84$ & $\mathrm{n} / \mathrm{a}$ & $\mathrm{n} / \mathrm{r}$ & 122.3 & $\begin{array}{l}\text { I: Free of CVD, not taking beta-blockers or } \\
\text { steroids or HRT. Free of chronic disease. Mod } \\
\text { PA }\end{array}$ \\
\hline $\begin{array}{l}\text { Sanada } 2010 \\
(27)\end{array}$ & onal & $\begin{array}{l}\text { Community } \\
\text { dwelling older adults }\end{array}$ & Japan & 959 & $50-50$ & 28 & 21.9 & $\mathrm{n} / \mathrm{r}$ & 125.9 & $\begin{array}{l}\text { I: active and free of CVD. E: use of beta- } \\
\text { blockers, steroids, HRT }\end{array}$ \\
\hline $\begin{array}{l}\text { Snijder } 2009 \\
(28)\end{array}$ & $\begin{array}{l}\text { Cross- } \\
\text { sectional }\end{array}$ & $\begin{array}{l}\text { Older men and } \\
\text { women with and } \\
\text { without diabetes }\end{array}$ & Netherlands & 456 & $50-50$ & 68.3 & 26.15 & 18.7 & $\mathrm{n} / \mathrm{r}$ & $\mathrm{n} / \mathrm{r}$ or unclear \\
\hline $\begin{array}{l}\text { Snijder } 2004 \\
(29)\end{array}$ & Cross- & $\begin{array}{l}\text { Older men and } \\
\text { women with and } \\
\text { without diabetes }\end{array}$ & Netherlands & 488 & $50-50$ & 69 & 26.4 & 22 & 140.7 & $\mathrm{n} / \mathrm{r}$ or unclear \\
\hline $\begin{array}{l}\text { Tabara } 2009 \\
\text { (30) }\end{array}$ & sectional & $\mathrm{ABI}>0.9$ & Japan & 407 & $40-60$ & 68 & 23.18 & 11.1 & 128.9 & $\mathrm{n} / \mathrm{r}$ or unclear \\
\hline $\begin{array}{l}\text { Wohlfahrt } \\
2015(31)\end{array}$ & $\begin{array}{l}\text { Cross- } \\
\text { sectional }\end{array}$ & Healthy, non-obese & USA & 136 & $44-56$ & 45 & 24.3 & $\mathrm{n} / \mathrm{a}$ & 114 & $\begin{array}{l}\text { I: Age } 30-65 y \text { BMI } 18.5-29.9 \mathrm{~kg} / \mathrm{m}^{2} \mathrm{E} \text { : liver } \\
\text { disease, ESRD, lung cancer, cancer, } \\
\text { hypertension, T2D, pregnancy, lactating, } \\
\text { excessive adiposity, metabolic diseases, previous }\end{array}$ \\
\hline
\end{tabular}

This article is protected by copyright. All rights reserved 


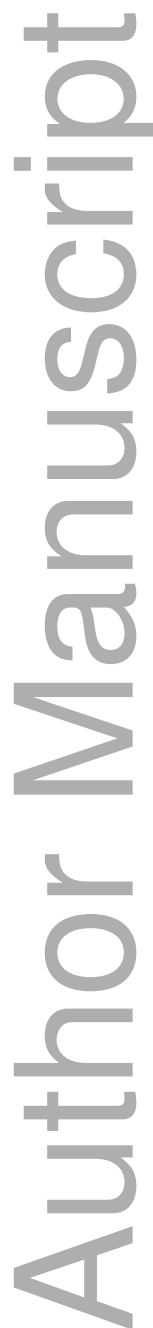

This article is protected by copyright. All rights reserved 
Table 2. Assessment of muscle tissue

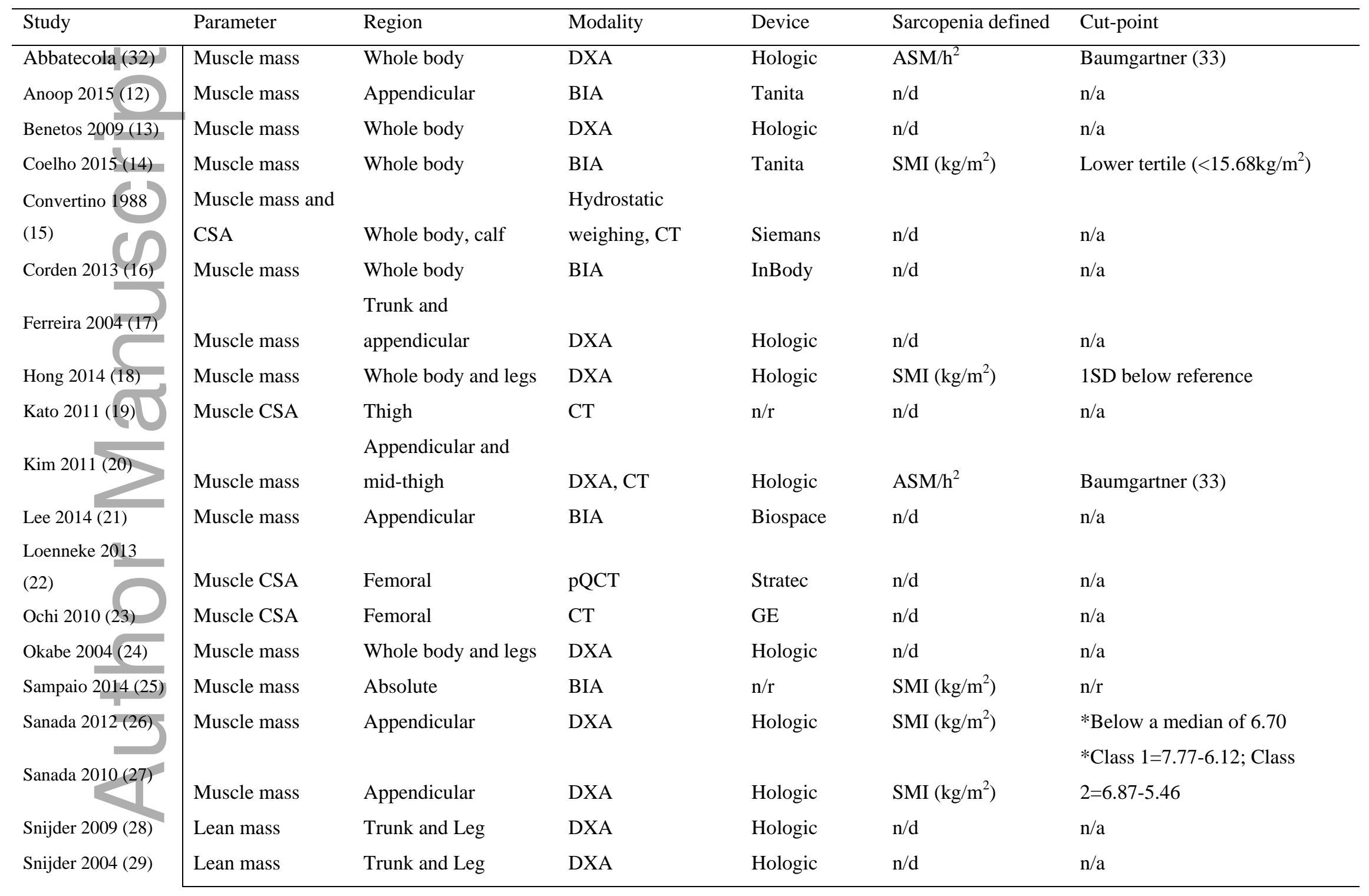

This article is protected by copyright. All rights reserved 


\begin{tabular}{|c|c|c|c|c|c|c|}
\hline Tabara 2009 (30) & Muscle CSA & Femoral & $\mathrm{CT}$ & GE & $\mathrm{n} / \mathrm{d}$ & $\mathrm{n} / \mathrm{a}$ \\
\hline Wohlfahrt 2015 & & Trunk and & & & & \\
\hline (31) & Lean mass & appendicular & DXA & GE Lunar & $\mathrm{n} / \mathrm{d}$ & $\mathrm{n} / \mathrm{a}$ \\
\hline
\end{tabular}

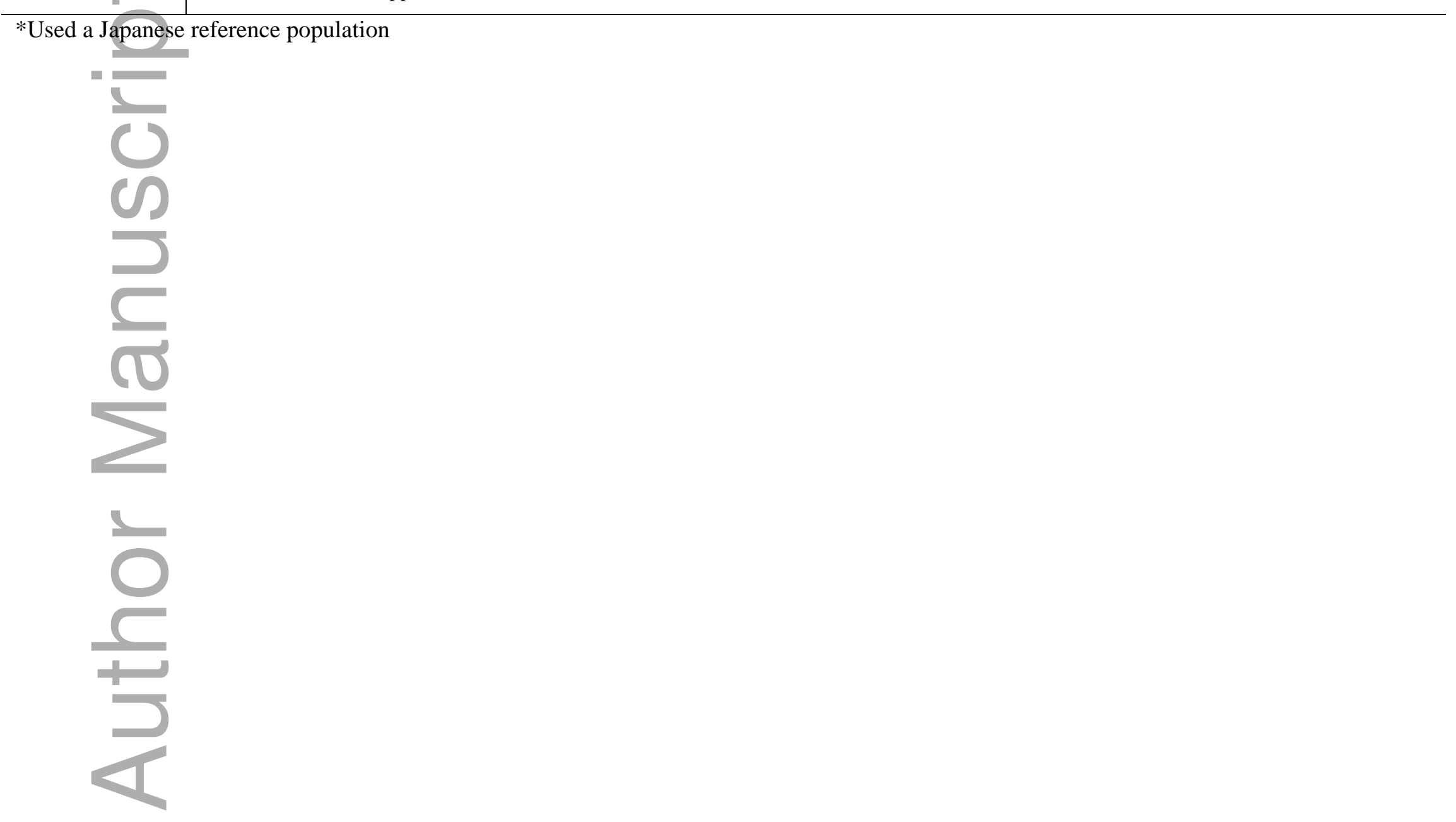

This article is protected by copyright. All rights reserved 
Table 3. Assessment of Arterial stiffness

\begin{tabular}{|c|c|c|c|c|}
\hline Study & Parameter & Vascular site & Method & Device \\
\hline Abbatecola (32) & PWV & Carotid-femoral & Doppler (transcutaneous probes) & Park Medical Electronics \\
\hline Anoop $2015(12)$ & PWV & Carotid-femoral & Applanation tonometry & SphygmoCor \\
\hline Benetos 2009 (13) & PWV & Carotid-femoral & Applanation tonometry & PulsePen \\
\hline Coelho 2015 & $\mathrm{PP}$ & $\mathrm{n} / \mathrm{a}$ & Oscillometric & Microlife \\
\hline Convertino 1988 (15) & Leg Compliance* & Calf & Oscillometric & $\mathrm{n} / \mathrm{r}$ \\
\hline Corden $2013(16)$ & PWV & Aortic arch & Flow waveform analysis & CMRtools (Cardiovascular Imaging Solutions) \\
\hline Ferreira 2004 (17) & PWV & Carotid-femoral & Volume-plethysmographic apparatus & Komaki \\
\hline Hong 2014 (18) & PWV & Brachial-ankle & Volume-plethysmographic apparatus & Komaki \\
\hline Kato 2011 (19) & PWV & Brachial-ankle & Oscillometric & Fukuda Denshi \\
\hline $\operatorname{Kim} 2011(20)$ & PWV & Brachial-ankle & Volume-plethysmographic apparatus & Komaki \\
\hline Lee $2014(21)$ & Aix & Radial & Pulse Wave Analysis & Omron \\
\hline Loenneke $2013(22)$ & Aix, PP & Radial & Applanation tonometry & SphygmoCor \\
\hline Ochi $2010(23)$ & PWV & Brachial-ankle & Volume plethysmographic apparatus & Omron \\
\hline Okabe $2004(24)$ & PWV & Brachial-ankle & Volume-plethysmographic apparatus & Komaki \\
\hline Sampaio $2014(25)$ & PWV & Carotid-ankle & Oscillometric & Fukuda Denshi \\
\hline Sanada 2012(26) & PWV & Brachial-ankle & Volume-plethysmographic apparatus & Komaki \\
\hline Sanada $2010(27)$ & PWV & Brachial-ankle & Volume-plethysmographic apparatus & Komaki \\
\hline Snijder $2009(28)$ & PWV & Carotid-femoral & Oscillometric & Collin Press-Mate \\
\hline Snijder 2004 (29) & PWV & Carotid-femoral & Oscillometric & Collin Press-Mate \\
\hline Tabara $2009(30)$ & PWV & Brachial-ankle & Oscillometric & Omron \\
\hline Wohlfahrt 2015 (31) & PWV & Carotid-femoral & Applanation tonometry & SphygmoCor \\
\hline
\end{tabular}

* Defined as \% change in blood volume relative to change in blood pressure

This article is protected by copyright. All rights reserved 
Table 4. Correlations and associations between lean tissue and arterial stiffness

\begin{tabular}{|c|c|c|c|c|c|c|c|c|c|c|}
\hline Study & Sample & $\mathrm{n}$ & Lean tissue & Outcome & $\mathrm{r}$ & $\mathrm{R}^{2}$ & $\beta$ & $\mathrm{p}$ & Adjustments & Meta-analysis \\
\hline \multirow[t]{10}{*}{ Anoop } & Female & 58 & Right leg & PWV & -0.21 & $\mathrm{n} / \mathrm{r}$ & $\mathrm{n} / \mathrm{r}$ & 0 & Unadjusted & $*$ \\
\hline & & & Left leg & PWV & -0.23 & $\mathrm{n} / \mathrm{r}$ & $\mathrm{n} / \mathrm{r}$ & 0 & Unadjusted & \\
\hline & & & Right arm & PWV & -0.07 & $\mathrm{n} / \mathrm{r}$ & $\mathrm{n} / \mathrm{r}$ & 0.55 & Unadjusted & \\
\hline & & & left arm & PWV & -0.02 & $\mathrm{n} / \mathrm{r}$ & $\mathrm{n} / \mathrm{r}$ & 0.56 & Unadjusted & \\
\hline & & & trunk & PWV & -0.04 & $\mathrm{n} / \mathrm{r}$ & $\mathrm{n} / \mathrm{r}$ & 0.74 & Unadjusted & \\
\hline & Male & 110 & Right leg & PWV & -0.16 & $\mathrm{n} / \mathrm{r}$ & $\mathrm{n} / \mathrm{r}$ & 0.09 & Unadjusted & $*$ \\
\hline & & & Left leg & PWV & -0.18 & $\mathrm{n} / \mathrm{r}$ & $\mathrm{n} / \mathrm{r}$ & 0.05 & Unadjusted & \\
\hline & & & Right arm & PWV & -0.18 & $\mathrm{n} / \mathrm{r}$ & $\mathrm{n} / \mathrm{r}$ & 0.05 & Unadjusted & \\
\hline & & & left arm & PWV & -0.18 & $\mathrm{n} / \mathrm{r}$ & $\mathrm{n} / \mathrm{r}$ & 0.04 & Unadjusted & \\
\hline & & & trunk & PWV & -0.19 & $\mathrm{n} / \mathrm{r}$ & $\mathrm{n} / \mathrm{r}$ & 0.04 & Unadjusted & \\
\hline Benetos & & 169 & Lean mass & PWV & $\mathrm{n} / \mathrm{r}$ & $\mathrm{n} / \mathrm{r}$ & -0.25 & 0.36 & Age, fat mass $(\mathrm{kg}), \mathrm{BMD}$ & \\
\hline \multirow[t]{2}{*}{ Coelho } & & 130 & SMI & PP & -0.7 & 0.49 & -0.226 & 0.05 & Unadjusted & \\
\hline & & & SMI & PP & -0.417 & 0.174 & 0.98 & $\mathrm{n} / \mathrm{s}$ & $\begin{array}{r}\text { Age, metabolic syndrome, smoking, HTN, DM, } \\
\text { height, physical function }\end{array}$ & \\
\hline \multirow[t]{2}{*}{ Convertino } & & 10 & Lean mass & Leg C & 0.39 & $\mathrm{n} / \mathrm{r}$ & $\mathrm{n} / \mathrm{r}$ & 0.26 & Unadjusted & \\
\hline & & & Calf CSA & Leg C & -0.61 & 0.04 & $\mathrm{n} / \mathrm{r}$ & 0.06 & Unadjusted & \\
\hline Corden & 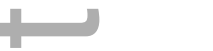 & 221 & LMI & PWV & -0.07 & $\mathrm{n} / \mathrm{r}$ & $\mathrm{n} / \mathrm{r}$ & 0.191 & Age, sex, MAP, \%body fat & $*$ \\
\hline \multirow[t]{2}{*}{ Hong } & & 552 & SMI & PWV & -0.16 & $\mathrm{n} / \mathrm{r}$ & $\mathrm{n} / \mathrm{r}$ & $<0.001$ & Age & $*$ \\
\hline & & 336 & PLM & PWV & & $\mathrm{n} / \mathrm{r}$ & -0.37 & $\mathrm{n} / \mathrm{r}$ & $\begin{array}{r}\text { Sex, height, MAP, body composition, } \mathrm{VO}_{2} \mathrm{max}, \\
\text { Total/HDL, TG. HbA1c, HR }\end{array}$ & \\
\hline \multirow[t]{2}{*}{ Kato } & All & 161 & TMA & PWV & -0.18 & $\mathrm{n} / \mathrm{r}$ & $\mathrm{n} / \mathrm{r}$ & $<0.05$ & Unadjusted & $*$ \\
\hline & non-DM & 127 & TMA & PWV & -0.18 & $\mathrm{n} / \mathrm{r}$ & $\mathrm{n} / \mathrm{r}$ & 0.09 & Unadjusted & $* *$ \\
\hline
\end{tabular}

This article is protected by copyright. All rights reserved 


\begin{tabular}{|c|c|c|c|c|c|c|c|c|c|c|}
\hline & DM & 34 & TMA & PWV & -0.24 & $\mathrm{n} / \mathrm{r}$ & $\mathrm{n} / \mathrm{r}$ & 0.24 & Unadjusted & $* *$ \\
\hline Loennecke & & 27 & Muscle CSA & PP & 0.166 & $\mathrm{n} / \mathrm{r}$ & $\mathrm{n} / \mathrm{r}$ & 0.428 & Height, sex & \\
\hline 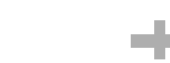 & & & Muscle CSA & Aix & -0.489 & $\mathrm{n} / \mathrm{r}$ & $\mathrm{n} / \mathrm{r}$ & 0.013 & Height, sex & \\
\hline Ochi & Men & 496 & Calf CSA & PWV & -0.34 & $\mathrm{n} / \mathrm{r}$ & $\mathrm{n} / \mathrm{r}$ & $<0.001$ & Weight & $*$ \\
\hline & Tomen & & Calf CSA & PWV & -0.09 & $\mathrm{n} / \mathrm{r}$ & $\mathrm{n} / \mathrm{r}$ & 0.1 & Weight & $*$ \\
\hline Okabe & & 24 & Muscle mass & baPWV & -0.67 & $\mathrm{n} / \mathrm{r}$ & $\mathrm{n} / \mathrm{r}$ & $<0.01$ & Age, BMC, fat mass, IMAT & $*$ \\
\hline & & & & faPWV & -0.627 & $\mathrm{n} / \mathrm{r}$ & $\mathrm{n} / \mathrm{r}$ & $<0.01$ & Age, BMC, fat mass, IMAT & \\
\hline Wohlfarht & & 136 & Arm & PWV & -0.424 & 0.18 & $\mathrm{n} / \mathrm{r}$ & $<0.05$ & Unadjusted & \\
\hline & & & Leg & PWV & -0.4 & 0.16 & $\mathrm{n} / \mathrm{r}$ & $\mathrm{n} / \mathrm{s}$ & Unadjusted & $*$ \\
\hline & & & Trunk & PWV & -0.4795 & 0.23 & $\mathrm{n} / \mathrm{r}$ & $<0.01$ & Unadjusted & \\
\hline & & & Total & PWV & -0.447 & 0.2 & $\mathrm{n} / \mathrm{r}$ & $<0.05$ & Unadjusted & \\
\hline Abbetecol & Men & 2272 & SI & PWV & -0.09 & $\mathrm{n} / \mathrm{r}$ & $\mathrm{n} / \mathrm{r}$ & 0.01 & $\begin{array}{l}\text { Age, diabetes, site, height, BMI, SBP, PAD, CHD, } \\
\text { smoking, IL-6, physical activity, race, }\end{array}$ & \\
\hline & & & arm & PWV & -0.106 & $\mathrm{n} / \mathrm{r}$ & $\mathrm{n} / \mathrm{r}$ & 0.0005 & $\begin{array}{l}\text { Age, diabetes, site, height, BMI, SBP, PAD, CHD, } \\
\text { smoking, IL-6, physical activity, race, }\end{array}$ & $*$ \\
\hline & & & leg & PWV & -0.217 & $\mathrm{n} / \mathrm{r}$ & $\mathrm{n} / \mathrm{r}$ & 0.0003 & $\begin{array}{l}\text { Age, diabetes, site, height, BMI, SBP, PAD, CHD, } \\
\text { smoking, IL-6, physical activity, race, }\end{array}$ & \\
\hline & nen & & arm & PWV & -0.0082 & $\mathrm{n} / \mathrm{r}$ & $\mathrm{n} / \mathrm{r}$ & 0.6849 & $\begin{array}{r}\text { Age, diabetes, site, height, BMI, SBP, PAD, CHD, } \\
\text { smoking, IL-6, physical activity, race, }\end{array}$ & $*$ \\
\hline
\end{tabular}

n.b. data shown in italics were sourced from authors or calculated from published data. $* *$ indicates data was treated separately in meta-analysis.

Abbreviations:Aix = augmentation index; $\mathrm{ba}=$ brachial-ankle; $\mathrm{BMC}=$ bone mineral content BMD = bone mineral density; $\mathrm{BMI}=$ body mass index $; \beta=\mathrm{Beta}$ coefficient $\mathrm{CHD}=$ coronary heart disease CSA = cross-sectional area; $\mathrm{DM}=$ diabetes mellitus; fa = femoral-ankle; HbA1c = glycated haemoglobin; $;$ HR = heart rate; HTN = hypertension; IL-6 = interleukin-6; IMAT = intramuscular fat; ; Leg C = leg compliance; LMI = lean mass index, MAP = mean arterial pressure; $\mathrm{n} / \mathrm{r}$ not reported; $\mathrm{PAD}=$ peripheral artery disease $\mathrm{PLM}=$ peripheral lean mass; $\mathrm{PP}=$ pulse pressure; $\mathrm{PWV}=$ pulse wave velocity $; \mathrm{r}=\mathrm{r}-\mathrm{correlation}$ coefficient; $\mathrm{R}^{2}=\mathrm{R}$-squared correlation coefficient; $\mathrm{SMI}=$ skeletal muscle index, $\mathrm{TG}=$ triglycerides $\mathrm{TMA}=$ thigh muscle area;

This article is protected by copyright. All rights reserved 
Table 5. Sensitivity analyses

\begin{tabular}{|c|c|c|c|c|c|c|}
\hline \multicolumn{2}{|c|}{ Stratification } & Studies (n) & Effect & $95 \% \mathrm{CI}$ & $\mathbf{p}$ & $\mathbf{I}^{2}$ \\
\hline \multirow{2}{*}{ Age } & Mean age $\geq 60 y$ & $2(2768)$ & -0.12 & $-0.22,-0.01$ & 0.02 & 85 \\
\hline & Mean age $<60 y$ & $5(1162)$ & -0.22 & $-0.35,-0.09$ & 0.0009 & 72 \\
\hline \multirow{2}{*}{ Imaging modality } & DXA & $4(2884)$ & -0.19 & $-0.32,-0.07$ & 0.002 & 89 \\
\hline & Non-DXA & 4 (1046) & -0.16 & $-0.22,-0.10$ & $<0.0001$ & 42 \\
\hline Muscle tissue & Regional & $4(961)$ & -0.24 & $-0.34,-0.13$ & $<0.0001$ & 59 \\
\hline
\end{tabular}

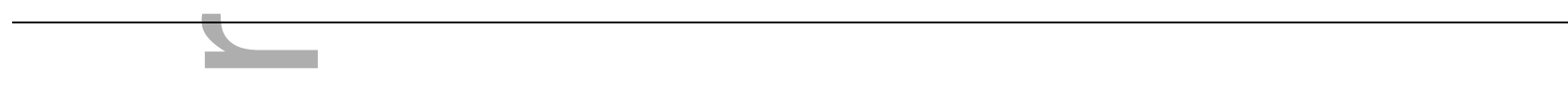


Table 6. Leave-one-out sensitivity analysis

\begin{tabular}{l|ccc}
\hline \multicolumn{1}{c|}{ Study omitted } & $\mathrm{n}$ & Fisher transformed r-correlation [95\% CI] & $\mathrm{p}$ \\
\hline Okabe 2004 & 3906 & $-0.16[-0.23,-0.08]$ & $<0.0001$ \\
Wolhfarht 2015 & 3794 & $-0.15[-0.22,-0.08]$ & $<0.0001$ \\
Ochi 2010 & 3434 & $-0.17[-0.25,-0.08]$ & $<0.0001$ \\
Anoop 2015 & 3762 & $-0.18[-0.27,-0.09]$ & $<0.0001$ \\
Kato 2011 & 3769 & $-0.18[-0.26,-0.09]$ & $<0.0001$ \\
Hong 2014 & 3508 & $-0.18[-0.27,-0.09]$ & $<0.0001$ \\
Abbatecola 2012 & 1658 & $-0.20[-0.30,-0.10]$ & $<0.0001$ \\
Corden 2013 & 3709 & $-0.19[-0.28,-0.11]$ & $<0.0001$ \\
\hline
\end{tabular}




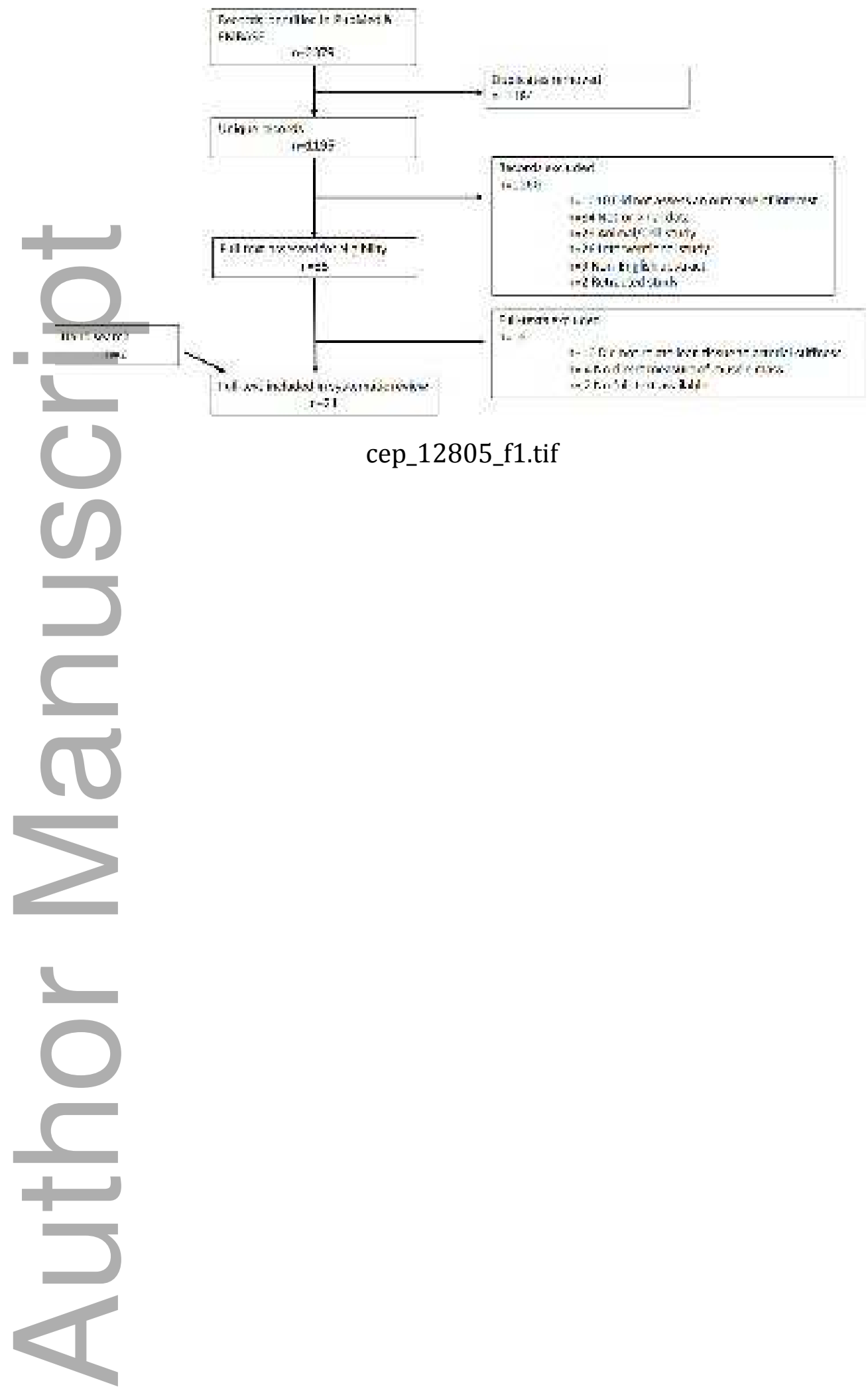

This article is protected by copyright. All rights reserved 


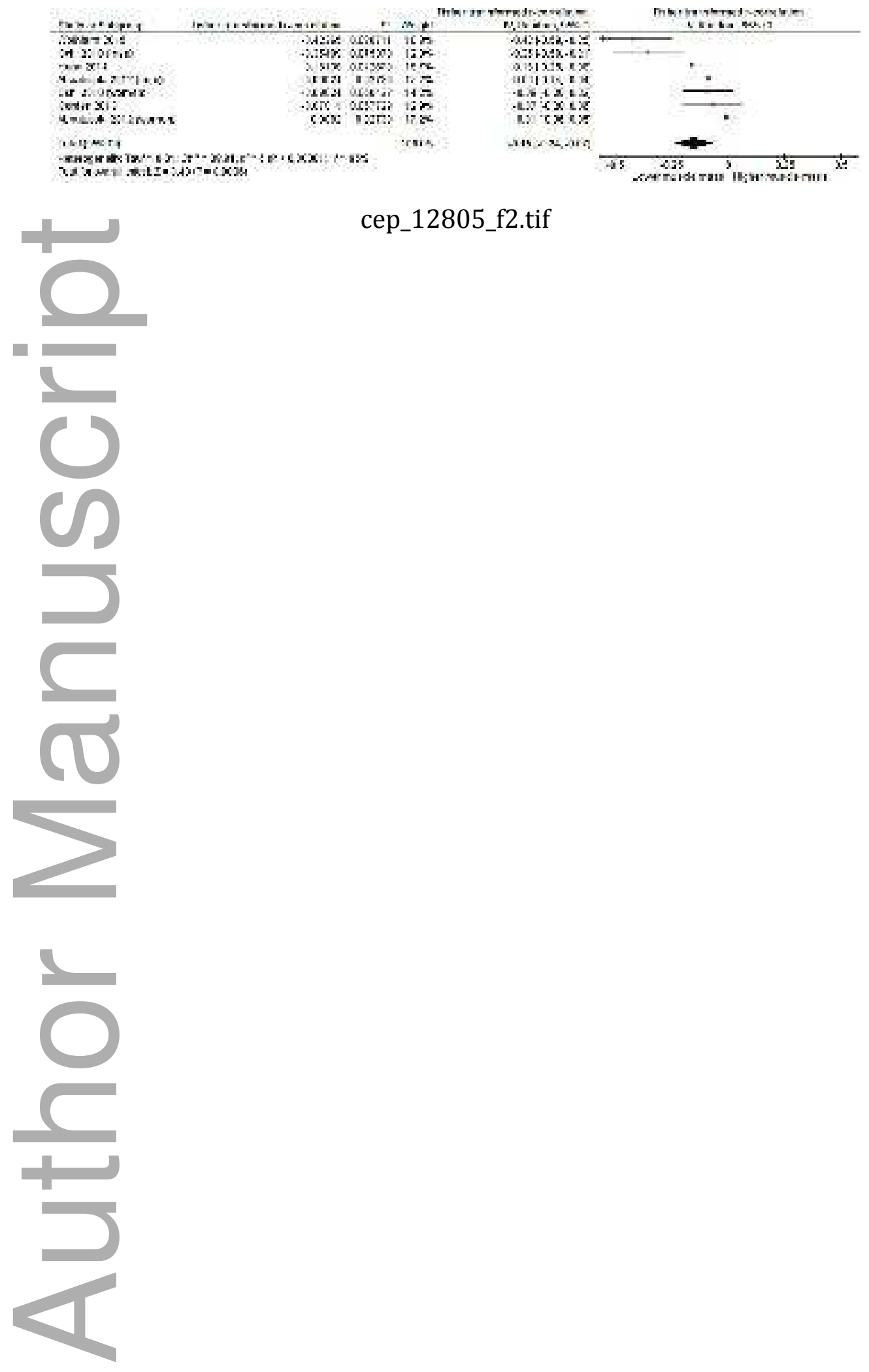

This article is protected by copyright. All rights reserved 


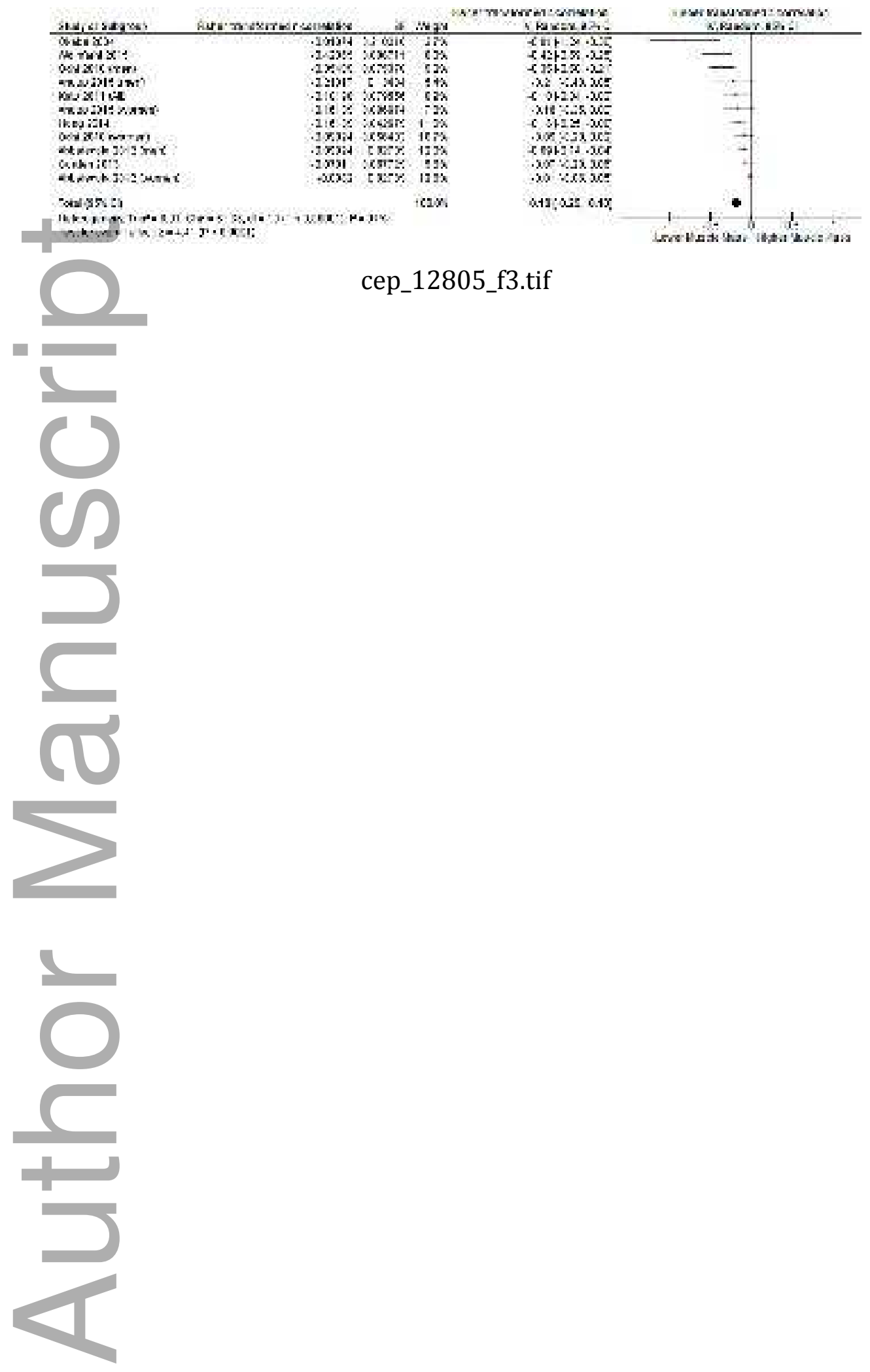

This article is protected by copyright. All rights reserved 


\section{University Library}

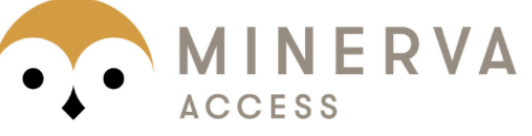

A gateway to Melbourne's research publications

Minerva Access is the Institutional Repository of The University of Melbourne

Author/s:

Rodriguez, AJ;Karim, MN;Srikanth, V;Ebeling, PR;Scott, D

Title:

Lower muscle tissue is associated with higher pulse wave velocity: A systematic review and meta-analysis of observational study data

Date:

2017-10-01

Citation:

Rodriguez, A. J., Karim, M. N., Srikanth, V., Ebeling, P. R. \& Scott, D. (2017). Lower muscle tissue is associated with higher pulse wave velocity: A systematic review and meta-analysis of observational study data. CLINICAL AND EXPERIMENTAL PHARMACOLOGY AND PHYSIOLOGY, 44 (10), pp.980-992. https://doi.org/10.1111/1440-1681.12805.

Persistent Link:

http://hdl.handle.net/11343/293361 